\title{
Product, pricing and promotional strategies of Restaurants in Nueva Ecija: An Assessment
}

\author{
Arjhel Valenton Domingo
}

\author{
Nueva Ecija University of Science and Technology, Nueva Ecija, Philippines \\ Email: arjhel_domingo@yahoo.com
}

\begin{abstract}
Marketing plays a very important role in the organization's success; it is a must to every organization to consider strategizing their different marketing practices. The study presented the marketing strategies of restaurants in Nueva Ecija. The study aimed to assess different marketing strategies which focused on product offering, pricing and promotion of the restaurants in the province. The descriptive method of research was utilized and questionnaire served as the instrument for collecting data. Owners/ managers of eight selected restaurants in Nueva Ecija were taken as respondents. As to product/service offerings, restaurants management offered variety of food and beverages to attract customers. They also maintained the cleanliness of their places and their surroundings. They based their prices on their production cost and current market demand. Meanwhile, advertising and sales promotion were the main promotional tool used by the restaurants management. On the other hand, the restaurants management should continuously provide new variety of high quality food offerings coupled with courteous and prompt services sold at a reasonable price.
\end{abstract}

Keywords - marketing; pricing; product; promotion; restaurants.

\section{INTRODUCTION}

Filipinos love to eat, and entrepreneurs know it. If you ask would-be-entrepreneurs about their opinion of the best business to start, a lot of them will answer - it should be food-related business. Indeed, food service business is one of the most competitive fields when it comes to business, specifically in income generation, growth and expansion.

In Nueva Ecija, restaurant business becomes an industry to watch out for as increasing number of this business is very evident mostly in the heart of the city. However, the increasing number of restaurants in the city manifests that competition gets stiffer. With this, only those businesses that geared with best practices and properly managed survive.

The extreme business competition and rapid changes in business environment have enticed many businesses into adopting businesses practices that are said to be of great help for them to achieve excellence status. These business practices are said to be the ways that have contributed to increasing the performance such as profitability and market share of the organization. Many of the owners of the businesses that have empowered their marketing practices are still in the running for the longest time and recognized as strongest contenders in the industry.

According to Marrs (2015), the competition among restaurants is fierce, and owners need to give their all to be successful. In order for a restaurant firm to stay on the industry owners should have some new fresh ideas. Restaurant owners must be vigilant on their marketing practices so that they will be able to survive competition.

In this study, the marketing strategies of restaurant businesses in Nueva Ecija in accordance with their products, pricing and promotion were described. This study will benefit the business owners as this study provided them information on their marketing practices for them to have benchmark. It is imperative therefore, for businesses to determine their best practices and continuously nurture these to keep their good standing. Moreover, this study will serve as a roadmap to the future entrepreneurs whose idea is to putting up a food business and giving them a clearer perspective on running this type of business, perhaps a slice of secrets in achieving business excellence.

\section{METHODOLOGY}

The research design utilized by the researchers in this study was the descriptive method. Questionnaire was used as the technique in gathering the data and additional interview questions prompted to the interest of the researchers. Questionnaire was structured based on the study of Sangkaworn, C. and Mujtaba, B., (n.d.). The respondents of the study were the owners of the eight selected restaurants in Nueva Ecija.

\section{RESULTS AND DISCUSSIONS}

1. Profile of the Restaurants 
Table.1: Profile of the Restaurants

\begin{tabular}{|l|c|c|}
\hline Description & $\mathrm{f}$ & $\%$ \\
\hline Type of ownership & & \\
\hline Sole proprietorship & 3 & 37.5 \\
\hline Partnership & 3 & 37.5 \\
\hline Corporation & 2 & 25 \\
\hline TOTAL & & 100 \\
\hline Number of employees & 0 & \\
\hline $4-6$ & 0 & 0 \\
\hline $7-9$ & 8 & 0 \\
\hline 10 and above & & 100 \\
\hline TOTAL & & 100 \\
\hline Years of Existence & 5 & 62.5 \\
\hline 2 to 5 years & 1 & 12.5 \\
\hline 6 to 8 years & 1 & 12.5 \\
\hline 9 to 11 years & 0 & 0 \\
\hline 12 to 14 years & 1 & 12.5 \\
\hline 15 years and above & & 100 \\
\hline TOTAL & & \\
\hline
\end{tabular}

Table 1 presents the profile of the restaurants. As to type of ownership, the table shows that three (3) restaurants were under sole proprietorship type, three (3) partnership and two (2) corporation. According to the owners, sole proprietorship is a type of business organization that is easier to manage. Partnership on the other hand, is preferred by some owners because of bigger resources that can be contributed among partners.

As to number of employees the eight restaurants have more than 10 employees. As business operation grows, restaurants employed more than 10 employees to cater growing number of customers coming to their place.

In addition, five (5) restaurants are operating for 2-5 years, one (1) is in business for 6-8 years the other one (1) is operating for 9-11 years and one (1) is in restaurant industry for more than 15 years now. Restaurant industry is fast-growing industry in Nueva Ecija as number of restaurants is increasing. According to the respondents, they really worked on their marketing strategies to survive the stiff competition and for them to stay longer in the said industry.

\section{Marketing Strategies of Restaurants}

\subsection{Product Offering}

Items 1, 4 and 6 got a weighed mean of 5.00 and rated "always". They considered the availability of variety of food and beverages, sanitation and cleanliness of the restaurant and their surroundings and prompt courteous service.
Table.2: Marketing Strategies of Restaurants in terms of Product Offering

\begin{tabular}{|c|c|c|c|}
\hline $\begin{array}{c}\text { Product/service } \\
\text { practices }\end{array}$ & $\begin{array}{l}\text { Weighted } \\
\text { mean }\end{array}$ & Description & Rank \\
\hline $\begin{array}{l}\text { Availability of } \\
\text { variety of food } \\
\text { and beverages. }\end{array}$ & 5 & Always & 2 \\
\hline $\begin{array}{l}\text { 2. Completeness } \\
\text { of dining } \\
\text { facilities }\end{array}$ & 4.75 & Always & 6.5 \\
\hline $\begin{array}{l}\text { 3. Availability of } \\
\text { parking space }\end{array}$ & 4.75 & Always & 6.5 \\
\hline $\begin{array}{l}\text { 4. Sanitation and } \\
\text { cleanliness of } \\
\text { the restaurant } \\
\text { and their } \\
\text { surroundings }\end{array}$ & 5 & Always & 2 \\
\hline $\begin{array}{ll}\text { 5. } & \text { Good and } \\
& \text { proper } \\
& \text { ventilation }\end{array}$ & 4.88 & Always & 4.5 \\
\hline $\begin{array}{ll}6 . & \text { Prompt } \\
& \text { courteous } \\
& \text { service }\end{array}$ & 5 & Always & 2 \\
\hline $\begin{array}{l}\text { 7. Attractiveness } \\
\text { of arrangement } \\
\text { of the place }\end{array}$ & 4.88 & Always & 4.5 \\
\hline
\end{tabular}

According to the respondents, they made it sure that all the foods/beverages in the menu are available so that customers will not be disappointed. In addition, they maintained a standard of cleanliness in all corners of restaurants. Furthermore, they have trained employees to be customer-friendly, accommodating and very welcoming. The restaurant owners also provided good and proper ventilation and made their place attractive.

These were the main factors that they considered in the operation of the business in order to attract and retain loyal customers.

\subsection{Pricing}

Table.3: Marketing Strategies of Restaurants in terms of Pricing

\begin{tabular}{|c|c|c|c|}
\hline Pricing practices & $\begin{array}{l}\text { Weighte } \\
\text { d mean }\end{array}$ & $\begin{array}{c}\text { Descriptio } \\
\mathrm{n}\end{array}$ & $\begin{array}{c}\text { Ran } \\
\mathrm{k}\end{array}$ \\
\hline $\begin{array}{ll}\text { 1. } & \text { Based on } \\
\text { cost/expense of } \\
\text { product }\end{array}$ & 4.63 & Always & 1 \\
\hline 2. $\quad$ Based on demand & 4.25 & Always & 3 \\
\hline 3. $\quad$ Discount & 4.38 & Always & 2 \\
\hline $\begin{array}{l}\text { 4. Based on the } \\
\text { price of } \\
\text { competitors }\end{array}$ & 3.75 & $\begin{array}{l}\text { Very } \\
\text { Often }\end{array}$ & 4 \\
\hline
\end{tabular}


As to pricing, item 1 got a weighted mean of 4.63. This means that cost/expense of the product was the primary basis in their pricing. Considerations number 2 weighted mean of 4.25 and rated "always". According to the respondents, they sometimes adjusted their prices based on the season/demand (e.i. Valentine's Day and Christmas). Item 3 got a weighted mean of 4.38 and rated "always". This means that they also offered discounts to their clients. Meanwhile, item 4 got a weighted mean of 3.75 and rated "very often". This denotes that they very often used the price of the competitors as their basis.

Since price is the only element among the P's of marketing mix that generates income, owners of the restaurants always see to it that prices are fair and affordable in order to retain customers .

\subsection{Promotion}

Table.4: Marketing Strategies of Restaurants in terms of Promotion

\begin{tabular}{|ll|c|c|c|}
\hline Promotion & $\begin{array}{c}\text { Weighted } \\
\text { mean }\end{array}$ & $\begin{array}{c}\text { Descriptio } \\
\mathrm{n}\end{array}$ & Rank \\
\hline 1. & $\begin{array}{l}\text { Giving customer } \\
\text { a discount }\end{array}$ & 4.38 & Always & 5 \\
\hline 2. & $\begin{array}{l}\text { Providing } \\
\text { additional } \\
\text { amenities such } \\
\text { WiFi, radio and } \\
\text { television plus } \\
\text { cable TV, } \\
\text { Telephone/interc } \\
\text { om }\end{array}$ & 4.88 & Always & 3 \\
\hline 3. & $\begin{array}{l}\text { Greeting } \\
\text { customers and } \\
\text { being friendly }\end{array}$ & 5 & Always & 1.5 \\
\hline 4. & $\begin{array}{l}\text { Providing } \\
\text { customers with } \\
\text { clean and } \\
\text { ventilated space }\end{array}$ & 5 & Always & 1.5 \\
\hline 5. & $\begin{array}{l}\text { Giving souvenirs } \\
\text { and gifts }\end{array}$ & 3.25 & Often & 6 \\
\hline
\end{tabular}

As to promotion, considerations 4 and 5 both got a weighted mean of 5.00 and rated "always". According to the respondents, they always provided customers with clean and ventilated spaces and they greeted customers and be friendly to them. On the other hand, item 1, and 2 got a weighted mean of 4.38 and 4.88 , respectively and rated "always". This implies that they gave discount to their customers and provided additional amenities such wifi, radio and television plus cable TV, telephone/intercom.

Primarily, sales promotion is one of the promotional tools used by the owners. The above sales promotion activities are the most common factors they considered in order to capture and maintain customers' loyalty, considering that customers are the ones who give income to the business.

Table.5: Ways of Advertising Restaurants

\begin{tabular}{|ll|c|c|c|}
\hline $\begin{array}{c}\text { Ways of advertising } \\
\text { restaurants }\end{array}$ & $\begin{array}{c}\text { Weighte } \\
\mathrm{d} \text { Mean }\end{array}$ & $\begin{array}{c}\text { Descriptio } \\
\mathrm{n}\end{array}$ & $\begin{array}{c}\text { Ran } \\
\mathrm{k}\end{array}$ \\
\hline 1. & Local radio & 1.88 & $\begin{array}{c}\text { Sometime } \\
\mathrm{s}\end{array}$ & 4 \\
\hline 2. & Local newspaper & 3.13 & Often & 3 \\
\hline 3. & $\begin{array}{l}\text { Brochures } \\
\text { distributed }\end{array}$ & 3.38 & Often & 1 \\
\hline 4. & Billboard nearby & 3.25 & Often & 2 \\
\hline
\end{tabular}

In terms of advertisement, owners often advertised their restaurants through brochures. According to them, budget was the main consideration in their advertising campaigns. Thus, they used the cheapest means of advertising such as brochures and billboards and through local newspapers and local radio stations.

\section{Implication of the study to Business Administration}

This study was conducted to find out the marketing strategies of selected restaurants of Nueva Ecija in terms of business-related factors which covered the type of ownership, number of employees, years of existence, the level of implementation of marketing strategies in terms of product offering, pricing and promotion. Since marketing now plays a very important role in the organization's success, it is a must to every organization to consider strategizing their different marketing practices. Presented herewith were the different considerations to which, if taken much attention would contribute to the success of company's marketing programs.

Attention on the product, pricing and promotion aspects of the business would lead you to having a higher impact on the industry you are into. In addition, since business is about earning money, giving special attention on marketing could give an organization a favourable profit.

\section{CONCLUSIONS AND RECOMMENDATIONS}

Based on the results of the study, majority of the restaurants were under sole proprietorship and partnership, with more than 10 employees and have operated for 2-5 years now. As to product/service offering, restaurant owners considered the availability of variety of food and beverages, sanitation and cleanliness of the restaurant and their surroundings and prompt courteous service. As to pricing, cost/expense of the product was the primary basis in setting prices of 
products. Whereas, advertising and sales promotion were the top promotion tools used by the restaurant owners.

Thus, restaurants' management have to improve customer satisfaction levels by providing a wide variety of products with high quality coupled with courteous and prompt services sold at a reasonable price. The restaurant owners should use other promotional techniques like social media in order to make the product more popular in the minds of existing and prospective customers. Furthermore, another study prior to the evaluation as to the effectiveness of marketing strategies of restaurants should be conducted.

\section{REFERENCES}

[1] Marrs, M. (2015, January 14). 25 Restaurant Marketing Ideas: Tips \& Strategies to Win in the Food Business. Retrieved from http://www.wordstream.com/blog/ws/2015/01/14/res taurant-marketing

[2] Sangkaworn, C., Mujtaba, B., (n.d.). Marketing practices of hotels and resorts in ChiangMai: a study of products, pricing, and promotional practices. $\quad$ Retrieved from http://www.aabri.com/manuscripts/09383.pdf 